Мельник Л. В., к.е.н., доцент (Національний університет водного господарства та природокористування, м. Рівне)

\title{
МЕТОДОЛОГІЧНІ ОСНОВИ ОЦІНКИ РЕСУРСНОГО ПОТЕНЦІАЛУ ІПОТЕЧНОГО КРЕДИТУВАННЯ В АГРАРНІЙ СФЕРІ
}

У статті досліджено теоретико-методологічні та практичні аспекти оцінки ресурсного потенціалу сільськогосподарських підприємств. Систематизовано методи оцінки ресурсного потенціалу. Охарактеризовано етапи оцінки ресурсного потенціалу іпотечного кредитування в аграрній сфері. Запропоновано систему показників оцінки ресурсного потенціалу іпотечного кредитування аграрної сфери. Визначено наслідки використання запропонованої методики. Ключові слова: іпотечне кредитування, ресурсний потенціал, методи оцінки ресурсного потенціалу, показники оцінки ресурсного потенціалу.

Однією з умов досягнення підприємствами аграрної сфери нових рівнів господарювання, активізації резервних можливостей, виходу на нові сегменти ринку є оптимізація процесу використання фінансового ресурсного потенціалу. 3 метою вирішення даної задачі лише теоретичного обґрунтування сутності та елементного складу ресурсного потенціалу недостатньо, для цього необхідно оцінити кількісний та якісний аспекти даного явища.

Теоретико-методологічним та практичним аспектам оцінки ресурсного потенціалу сільськогосподарських підприємств та питанням ефективного використання механізмів іпотечного кредитування приділяють увагу багато вітчизняних та зарубіжних вчених та експертів, зокрема В. Базилевич, Ю. Гудзь, З. Зав'ялова, М. Ельдієв, М. Іванов, П. Нуттунен, О. Старікова, Ю. Умавов та ін. Аналіз досліджень вчених-економістів свідчить про відсутність єдиної думки в сучасній економічній науці стосовно методики кількісного вираження ресурсного потенціалу. Важливим та недостатньо дослідженим $€$ питання формування та використання ресурсного потенціалу іпотечного кредитування в аграрній сфері.

Метою даної статті $€$ визначення методологічних основ оцінки ресурсного потенціалу іпотечного кредитування аграрної сфери.

В сучасній економічній науці існує численна кількість методів дослідження та оцінювання ресурсного потенціалу та його елементів, 
що на виході дають достовірні результати, використання яких дозволяє приймати правильні управлінські рішення в умовах нестабільності та невизначеності [1]. В таблиці наведена систематизована класифікація методів оцінки стану та ефективності використання ресурсного потенціалу.

Таблиця

Класифікація методів оцінки ресурсного потенціалу

\begin{tabular}{|c|c|}
\hline Назва методу & Сутність методу \\
\hline \multicolumn{2}{|c|}{ За напрямками наповнення інформаційної бази } \\
\hline $\begin{array}{c}\text { Критеріальні } \\
\text { методи }\end{array}$ & $\begin{array}{l}\text { Збір та обробка інформаційного масиву здійсню- } \\
\text { ється на базі звітної та (або) планової документації } \\
\text { з використанням абсолютних і відносних показни- } \\
\text { ків. Дана методика характеризується точністю у } \\
\text { зв'язку з достовірністю і попередньою детерміно- } \\
\text { ваністю вихідних даних. Даний метод є доцільним } \\
\text { для використання у масштабних структурах, оскі- } \\
\text { льки існує необхідність обробки великих масивів } \\
\text { інформації та здійснення складних і об'ємних роз- } \\
\text { рахунків }\end{array}$ \\
\hline $\begin{array}{l}\text { Експертні } \\
\text { методи }\end{array}$ & $\begin{array}{l}\text { Аналіз здійснюється на основі експертних оцінок. } \\
\text { Методика не відрізняється високою точністю, оскі- } \\
\text { льки базується на стохастичних даних, проте до- } \\
\text { зволить сформувати приблизні оцінки стану потен- } \\
\text { ціалу за умов відсутності повноти інформаційного } \\
\text { масиву. Кінцевим результатом при цьому є інтегра- } \\
\text { льний показник ефективності використання ресур- } \\
\text { сного потенціалу, що формується внаслідок зве- } \\
\text { дення низки окремих показників, які характеризу- } \\
\text { ють визначальні фактори впливу. Дана група мето- } \\
\text { дів застосовується, зокрема, з метою аналізу поте- } \\
\text { нційних можливостей конкурентів }\end{array}$ \\
\hline \multicolumn{2}{|c|}{ За способом представлення кінцевих результатів } \\
\hline $\begin{array}{l}\text { Графічні } \\
\text { методи }\end{array}$ & $\begin{array}{l}\text { Використовуються з метою наочного представлен- } \\
\text { ня результатів аналітичних розрахунків, що зобра- } \\
\text { жуються за допомогою графічних об'єктів (схем, } \\
\text { графіків, діаграм, рисунків). Зручність представ- } \\
\text { лення і сприйняття графічно представленої аналі- } \\
\text { тичної інформації компенсується зниженням точно- } \\
\text { сті за рахунок наближеності функції взаємозв'язків } \\
\text { між факторними та результативною ознаками }\end{array}$ \\
\hline
\end{tabular}


продовження таблиці

\begin{tabular}{|c|c|}
\hline $\begin{array}{c}\text { Економіко- } \\
\text { статистичне } \\
\text { моделювання }\end{array}$ & $\begin{array}{l}\text { Використання даної методики засноване на форму- } \\
\text { ванні алгоритмів розрахунків показників, що хара- } \\
\text { ктеризують ресурсний потенціал, створення та } \\
\text { аналіз економетричних моделей за факторами } \\
\text { впливу на систему. Статистичні моделі з викорис- } \\
\text { танням різноманітних математичних функцій, коре- } \\
\text { ляційно-регресійного аналізу мають високу точ- } \\
\text { ність, проте складність їх розрахунку зумовлює по- } \\
\text { требу в спеціалізованому технічному і програмному } \\
\text { забезпеченні }\end{array}$ \\
\hline $\begin{array}{l}\text { Методи } \\
\text { логічного } \\
\text { аналізу }\end{array}$ & $\begin{array}{l}\text { Ґрунтуються на логічних алгоритмах та висновках, } \\
\text { що дозволяють в короткий час отримати наближені } \\
\text { результати без значних витрат. Доцільні до засто- } \\
\text { сування у випадку неможливості моделювання } \\
\text { конкретних процесів та явищ }\end{array}$ \\
\hline $\begin{array}{l}\text { Індексні } \\
\text { методи }\end{array}$ & $\begin{array}{l}\text { Базується на формуванні багатомірної середньої } \\
\text { шляхом стандартизації різнойменних показників в } \\
\text { іменовані величини (коефіцієнти, індекси, бали), що } \\
\text { піддаються сумуванню. Результативним показни- } \\
\text { ком є агрегатний індекс, що характеризує сукуп- } \\
\text { ність різнорідних складових ресурсного потенціалу }\end{array}$ \\
\hline $\begin{array}{l}\text { Методи } \\
\text { грошової } \\
\text { оцінки }\end{array}$ & $\begin{array}{l}\text { Застосування даного методу полягає у грошовому } \\
\text { вираженні елементів ресурсного потенціалу на ос- } \\
\text { нові принципу субституційності ресурсів. Величина } \\
\text { ресурсного потенціалу визначається сумою вартіс- } \\
\text { ної оцінки його складових }\end{array}$ \\
\hline & За способом виконання \\
\hline $\begin{array}{c}\text { Метод } \\
\text { індикаторів }\end{array}$ & $\begin{array}{l}3 \text { метою оцінки ефективності використання ресурс- } \\
\text { ного потенціалу формується система індикаторів, } \\
\text { що є визначальними для кожного елементу потен- } \\
\text { ціалу. При цьому індикатори є системами співвід- } \\
\text { ношень абсолютних та відносних показників, що } \\
\text { найбільш вичерпно характеризують різні аспекти } \\
\text { складових ресурсного потенціалу }\end{array}$ \\
\hline $\begin{array}{l}\text { Матричні } \\
\text { методи }\end{array}$ & $\begin{array}{l}\text { Призначені для здійснення системної оцінки ресур- } \\
\text { сного потенціалу, враховуючи як стан та динаміку } \\
\text { окремих складових системи, так і взаємозв'язків } \\
\text { між ними }\end{array}$ \\
\hline
\end{tabular}


продовження таблиці

\begin{tabular}{|c|c|}
\hline \multicolumn{2}{|c|}{ Відносно динамічності досліджуваних процесів } \\
\hline & $\begin{array}{l}\text { Застосовуються для оцінки фактичного стану ресу- } \\
\text { рсного потенціалу з метою екстраполяції даних для } \\
\text { побудови кривої результатів майбутніх періодів. } \\
\text { Дана методикає ефективною для прийняття опера- } \\
\text { тивних управлінських рішень з акумуляції і спряму- } \\
\text { вання наявних ресурсів в процесі економічної дія- } \\
\text { льності, проте не забезпечує належного перспекти- } \\
\text { вного проектування }\end{array}$ \\
\hline $\begin{array}{c}\text { Методи } \\
\text { стратегічного } \\
\text { аналізу }\end{array}$ & $\begin{array}{l}\text { Дана група методів ґрунтується на створенні дина- } \\
\text { мічних моделей процесів формування та викорис- } \\
\text { тання ресурсного потенціалу, що широко застосо- } \\
\text { вуються при стратегічному плануванні діяльності } \\
\text { суб'єктів господарювання та моделей їх поведінки у } \\
\text { конкурентному середовищі }\end{array}$ \\
\hline
\end{tabular}

Джерело: складено автором на основі $[1 ; 2 ; 3 ; 4 ; 5]$.

Гармонічний стан рівноваги ресурсного потенціалу іпотечного кредитування аграрної сфери забезпечується сукупною дією численних зовнішніх та внутрішніх факторів впливу, кожен з яких може брати участь у формуванні одночасно кількох компонентів ресурсного потенціалу, що зумовлює синергетичний ефект системи в цілому. Ці складові органічно пов'язані між собою в межах існуючих соціально-економічних відносин. Враховуючи вищевказані об'єкти досліджень, формуються методологічні підходи до оцінки обсягів та ефективності використання ресурсного потенціалу.

Здійснення аналізу ресурсного потенціалу іпотечного кредитування пропонується проводити поетапно, з урахуванням особливостей провадження господарської діяльності підприємств аграрної сфери та умов їх кредитування під заставу нерухомості [1].

В основі першого етапу процесу оцінювання ресурсного потенціалу іпотечного кредитування лежить аналітично-синтетичний підхід, що передбачає, насамперед, декомпозицію системного явища ресурсного потенціалу на складові підсистеми та підбір групи показників, що максимально об'єктивно характеризують кожен елемент потенціалу, з подальшим інтегруванням кожного характерного показника у підсумкову комплексну оцінку ресурсного потенціалу.

Важливим етапом в аналітичному процесі $є$ збір об'єктивної статистичної інформації про стан та динаміку явищ та процесів в системі іпотечного кредитування аграрної промисловості. Динаміку та тенденції розвитку показників ресурсного потенціалу іпотечного 
кредитування доцільно досліджувати у часовому проміжку, що охоплює не менше, ніж 5 останніх років господарської діяльності аграрних підприємств та фермерських господарств, а також банківських, інвестиційних та страхових установ, що їх обслуговують, із врахуванням ролі держави в процесі розвитку сільськогосподарського виробництва.

Аналіз ресурсного потенціалу іпотечного кредитування в аграрній сфері повинен проводитись не лише за компонентами потенціалу, а й в розрізі областей України. Аналітичний огляд кожного компонента ресурсного потенціалу за визначеними показниками в абсолютному, відносному та нормованому вигляді в територіальному розрізі дозволить порівняти кожен регіон з середніми значеннями по країні, ранжувати області за рівнем відповідних показників у чотири кластери: I - високий рівень потенціалу, II - рівень потенціалу вище середнього, III - рівень потенціалу нижче середнього, IV - низький рівень потенціалу.

Синтез нормованих показників у комплексну оцінку ресурсного потенціалу іпотечного кредитування в аграрній сфері дозволить проаналізувати рівень потенціалу в регіональному розрізі з метою виявлення груп областей, що належать до кожного з чотирьох кластерів ресурсного потенціалу іпотечного кредитування, з виявленням сильних та слабких потенційних можливостей кожного регіону.

Наступним етапом в оцінці ресурсного потенціалу є виявлення визначальних факторів впливу на результативний показник, розробка моделі формування і використання ресурсного потенціалу, а також прогнозування найбільш ефективних методів використання наявного ресурсного потенціалу іпотечного кредитування з метою розвитку аграрної сфери та шляхів його підвищення.

Завершальним етапом у процесі даного наукового дослідження $€$ розробка трьох варіантів сценаріїв - оптимістичного, реалістичного та песимістичного - подальшого розвитку системи іпотечного кредитування аграрної сфери, в основі якої лежить ресурсний потенціал в якості фундаментальної бази для забезпечення сталого соціальноекономічного розвитку регіонів України.

Виходячи з багатоелементності структури ресурсного потенціалу іпотечного кредитування сільського господарства, з метою його достовірної оцінки пропонується створити комплекс адекватних економіко-статистичних та вербальних показників, які дозволять охопити різні аспекти існування та взаємодії об'єкта оцінки, врахувавши при цьому широкий спектр визначальних факторів впливу на власне ресурсний потенціал в цілому [6]. Таким чином, у процесі оцінювання 
стану та ефективності використання ресурсного потенціалу іпотечного кредитування в аграрній сфері та його компонентів варто використовувати наступну систему кількісних та якісних показників:

Заставний потенціал:

- оціночна вартість сільськогосподарських угідь, що не знаходяться в обороті, тис. грн $\left(X_{1}\right)$;

- оціночна вартість майна аграрних підприємств та фермерських господарств, тис. грн (X2);

- коефіцієнт вартості позики, \% $\left(X_{3}\right)$.

Інвестиційний потенціал:

- фондоозброєність суб'єктів господарювання в аграрній сфері, грн/чол. (X4);

- коефіцієнт зношеності основних фондів аграрних підприємств та фермерських господарств, \% (X5);

- кількість комбайнів на одиницю площі земель сільськогосподарського призначення, од./тис. га (Х6);

- середні капіталовкладення на 1 інвестиційний проект, тис. грн (X7).

Інституційний потенціал:

- $\quad$ кількість іпотечних установ, од. $\left(X_{8}\right)$;

- кількість аграрних підприємств та фермерських господарств в розрахунку на 1 іпотечну установу, од. $\left(X_{9}\right)$;

- $\quad$ кількість страхувальників іпотечних кредитів, од. $\left(X_{10}\right)$.

Фінансовий потенціал:

- відношення інвестицій в основний капітал до обсягів іпотечних кредитів, \% $\left(X_{11}\right)$;

- обсяг іпотечних кредитів, виданих в аграрну сферу, тис. грн. $\left(X_{12}\right)$;

- обсяг випущених іпотечних облігацій, тис. грн $\left(X_{13}\right)$;

- відношення довгострокових пасивів банківських установ до обсягів їх довгострокових активів, \% $\left(X_{14}\right)$;

- структура довгострокових активів банків, у \% до підсумку;

- відсоткові ставки за іпотечними кредитами, \% $\left(X_{15}\right)$;

- співвідношення відсоткових ставок за іпотечними кредитами до відсотків за депозитами, \% $\left(X_{16}\right)$;

- відношення рентабельності аграрних підприємств до відсотків за іпотечними кредитами, \% $\left(X_{17}\right)$.

Регуляторний потенціал:

- частка державних коштів, спрямованих в іпотечну сферу за державними програмами підтримки сільського господарства, у загальному обсязі іпотечного кредитування, \% $\left(X_{18}\right)$; 
- обсяги державного фінансування аграрної сфери, млн грн. $\left(X_{19}\right)$;

- відношення відсоткових ставок за державними програмами до відсоткових ставок за комерційними іпотечними кредитами, \% $\left(X_{20}\right)$;

- динаміка коефіцієнтів фінансового стану позичальників до і після одержання фінансової підтримки за державними програмами розвитку сільського господарства.

Використання на практиці наведеної методики оцінювання стану та ефективності використання ресурсного потенціалу іпотечного кредитування аграрної сфери дозволить реалізувати наступні напрямки покращання стану регіонів та країни в цілому, а саме:

- забезпечення притоку інвестицій в новітні технології ведення сільськогосподарського виробництва;

- покращення фінансового становища та добробуту середніх і малих фермерських господарств;

- зростання зайнятості населення у сільській місцевості, що відіграє ключове значення у комплексному розвитку депресивних регіонів;

- збільшення заробітної платні, надання освітніх, соціальних, оздоровчих послуг на якісно новому рівні;

- інтенсифікація надходжень до місцевих та державного бюджетів;

- покращення екологічного становища у районах, де вже виснажені або знаходяться на критичному рівні експлуатації природні ресурси, забезпечення їх ефективного відновлення;

- оптимізація кількісного та вікового градуювання населення по території України, повернення молоді у села;

- забезпечення продовольчої безпеки країни силами вітчизняних виробників сільськогосподарської продукції;

- підвищення якості вітчизняної сільськогосподарської продукції відповідно до міжнародних стандартів якості, зростання експорту сільськогосподарських продуктів кінцевого споживання, а не лише сировинних ресурсів;

- активізація комплексного розвитку галузей економіки, тісно або опосередковано пов'язаних з розвитком АПК - машинобудування сільськогосподарської техніки різноманітних габаритів, розвитку інфраструктури, виготовлення мінеральних добрив, харчової, текстильної, хімічної промисловості, фармакології, фінансово-кредитної сфери, зокрема й іпотечної, а 
також похідних галузей - туризму, ресторанно-готельного бізнесу, рекреаційно-оздоровчої сфери.

Таким чином, завдяки запропонованому методичному підходу до поліаспектної оцінки ресурсного потенціалу іпотечного кредитування в аграрній сфері можна визначити не лише стан та ефективність використання потенціалу та водночас наділити органи державної влади альтернативними інструментами впливу на соціальноекономічні явища й процеси, що циркулюють у сфері реалізації економічного потенціалу регіону та забезпечення сталого соціальноекономічного розвитку.

1. Бугара А.Н. Теоретические подходы к оценке ресурсного потенциала в сельскохозяйственных предприятиях. Международный научнопрактический журнал «Агропродовольственная экономика». URL: http://apej.ru/article/02-10-2017 (дата звернення : 01.10.2018). 2. Зав'ялова 3. М., Выголова И. Н. Методические подходы к оценке ресурсного потенциала сельскохозяйственных предприятий. Интеллект. Инновации. Инвестиции. № 3. 2011. С. 103-106. 3. Иванов М. А. Методы оценки ресурсного потенциала сельскохозяйственных предприятий. Вестник Курской государственной сельскохозяйственной академии. № 1. 2015. С. 22-23. 4. Кожевникова И. В. Региональные приоритеты формирования и использования производственного потенциала в сельском хозяйстве. Вестник Сев-КавГТУ. Экономика. № 1. 2004. С. 175-181. 5. Эльдиев М. Д., Эльдиева Т. М., Эпов И. 0. Ресурсный потенциал как важный фактор сбалансированного развития сельских территорий. Научно-технические ведомости СПбГПУ. Экономические науки. № 2(192). 2014. С. 48-56. 6. Федоров М. Н., Волков А. Б. Ресурсный потенциал сельскохозяйственной организации как система. Научный журнал «Евразийский союз учёных». Экономические науки. № 24. 2016. URL: http://euroasia-science.ru/ekonomicheskie-nauki/resursnyj-potencialselskoxozyajstvennoj-organizacii-kak-sistema/ (дата звернення : 08.10.2018).

\section{REFERENCES :}

1. Buhara A. N. Teoretycheskye podkhodb k otsenke resursnoho potentsyala $v$ selskokhoziaistvennykh predpryiatyiakh. Mezhdunarodnyi nauchnopraktycheskii zhurnal «Ahroprodovolstvennaia ekonomyka». URL: http://apej.ru/article/02-10-2017 (data zvernennia : 01.10.2018). 2. Zavialova Z. M., Vyholova Y. N. Metodicheskye podkhody k otsenke resursnoho potentsyala selskokhoziaistvennykh predpriiatii. Intellekt. Innovatsyi. Investy-tsyi. № 3. 2011. S. 103-106. 3. Yvanov M. A. Metodb otsenky resursnoho potentsyala selskokhoziaistvennukh predpryiatyi. Vestnik Kurskoi hosudarstvennoi selskokhoziaistvennoi akademii. № 1. 2015. S. 22-23. 4. Kozhevnikova Y. V. Rehionalnye prioritety formirovanyia i ispolzovaniia 
proizvodstvennoho potentsyala $v$ selskom khoziaistve. Vestnik Sev-KavHTU. Ekonomyka». № 1. 2004. S. 175-181. 5. Eldyev M. D., Eldyeva T. M., Epov Y. 0. Resursnyi potentsyal kak vazhnyi faktor sbalansirovannoho razvitiia selskikh territorii. Nauchno-tekhnicheskye vedomosti SPbHPU. Ekonomicheskie nauki. № 2(192). 2014. S. 48-56. 6. Fedorov M. N., Volkov A. B. Resursnyi potentsyal selskokhoziaistvennoi orhanyzatsyy kak sistema. Nauchnyi zhurnal «Evraziiskyi soiuz uchenykh». Ekonomicheskie nauki. № 24. 2016. URL: http://euroasia-science.ru/ekonomicheskie-nauki/resursnyj-potencialselskoxozyajstvennoj-organizacii-kak-sistema/ (data zvernennia : 08.10.2018).

Рецензент: д.е.н., професор Савіна Н. Б. (НУВГП)

Melnyk L. V., Candidate of Economics (Ph. D.), Associate Professor (National University of Water and Environmental Engineering, Rivne)

\section{ESTIMATION METHODOLOGICAL BASIS OF RESOURCE POTENTIAL OF MORTGAGE LENDING IN AGRARIAN SPHERE}

One of the conditions for the achievement by the enterprises of the agrarian sphere of new levels of economic activity is an objective assessment of financial resource potential. An analysis of the mortgage lending potential has been proposed to be carried out in stages. At the first stage, there is a collection of statistical information on the state and dynamics of processes in the system of mortgage lending to the agrarian industry. The analysis is carried out according to the components of the potential: mortgage potential, institutional capacity, regulatory potential and in terms of regions. The next step is to identify the determinants of the impact on the performance indicator, to develop a model for the formation and use of resource potential, as well as to forecast the most effective methods for using the available resource potential of mortgage lending. The final stage is the development of options for further development of the system of mortgage crediting of the agrarian sector, which is based on the resource potential as a fundamental basis.

Keywords: mortgage lending, resource potential, methods of resource potential assessment, indicators of resource potential assessment. 
Мельник Л. В., к.э.н., доцент (Национальный университет водного хозяйства и природопользования, г. Ровно)

\section{МЕТОДОЛОГИЧЕСКИЕ ОСНОВЫ ОЦЕНКИ РЕСУРСНОГО ПОТЕНЦИАЛА ИПОТЕЧНОГО КРЕДИТОВАНИЯ В АГРАРНОЙ СФЕРЕ}

В статье исследованы теоретико-методологические и практические аспекты оценки ресурсного потенциала сельскохозяйственных предприятий. Систематизированы методы оценки ресурсного потенциала. Охарактеризованы этапы оценки ресурсного потенциала ипотечного кредитования в аграрной сфере. Предложена система показателей оценки ресурсного потенциала ипотечного кредитования аграрной сферы. Определены последствия использования предложенной методики.

Ключевые слова: ипотечное кредитование, ресурсный потенциал, методы оценки ресурсного потенциала, показатели оценки ресурсного потенциала. 